\title{
The Experimental Study of Kinesthetic Style Student Learning Outcomes in Remedial Teaching Assisted by Projectile Motion Props
}

\author{
Sari Eka Putri ${ }^{\text {a) }}$, Iwan Permana Suwarna ${ }^{\text {b) }}$ \\ Physics Education Study Program, FITK, Syarif Hidayatullah State Islamic University, 15412 \\ Jakarta, Indonesia

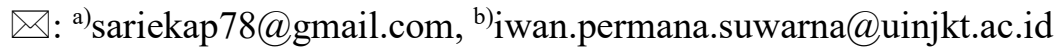

\begin{abstract}
The main problem of this study is that students who are not able to gain the minimum score were not given remedial teaching and learning that were adjusted to their learning style. This study aimed to determine the effect, improvement, and effectiveness of the use of projectile motion props in remedial teaching on kinesthetic style students learning outcomes and students' response to the use of the props. The research method used in this study was a quasi-experiment with nonequivalent control group design. Hypothesis test results of the post-test results with the Mann-Whitney $U$ test at the confidence level of $95 \%(\alpha=0.05)$ obtained the significance value (2-tailed) that was 0.000 . Alternative research hypotheses $\left(H_{l}\right)$ were accepted (there were effects of projectile motion props on remedial teaching on kinesthetic style student learning outcomes). The kinesthetic style student in the experimental group successfully gained 0.64 (middle category) in their learning outcomes, and the controlled group students gained less only 0.31 (middle category) in their learning outcomes. In the cognitive domain of $\mathrm{C} 2$ (understanding), the experimental group students experienced the highest increase, which was 0.72 , while the controlled group gained only 0.50 . The effectiveness of remedial teaching in the experimental group was very effective (80\%); meanwhile, in the controlled group, it showed ineffectiveness $(28 \%)$. Students of kinesthetic style's response are very good $(81 \%)$ on the use of projectile motion props.
\end{abstract}

Keywords: kinesthetic style, learning outcomes, projectile motion, projectile motion props, remedial teaching

\section{INTRODUCTION}

The process of learning physics in some areas on the concept of projectile motion is still facing problems. Most students feel that the learning of physics is not per their learning styles, such as kinesthetic style students do not get kinesthetic treatment. Marthafiani stated that learning physics at SMAN 4 South Tangerang City still uses conventional methods, kinesthetic style students only listen to the teacher's explanation without doing practicum activities because of the limited practical tools at school (Putri 2019). The method causes difficulties for kinesthetic students in learning the projectile motion concept. The students' difficulties include: determining the magnitudes of the projectile motion and difficult to distinguish the use of the right formula (Putri 2019). Students find it difficult to visualize 
the path of movement of objects after being given the initial angle. They cannot predict the farthest distance of objects after being given different angles (Wicaksana 2017). Discussion of the concept of parabolic motion requires skills in combining the concept of motion with the concept of vectors (Saepuzaman \& Karim 2016). These difficulties cause students to experience remedial on projectile motion concepts. The solution is remedial tests and assignments, regardless of the number of students who have not completed (Putri 2019). The handling solutions handed by the teachers are not appropriate because it is not following the theory of implementing remedial learning. In theory, if the number of incomplete students $>50 \%$ must be overcome by remedial learning (Direktorat Pembinaan SMA 2010). Many students in the South Tangerang who did not complete the concept of projectile motion were $72.4 \%$ (Putri 2019). Marthafiani stated that many students' scores after taking the remedial test were still under the MCC (Minimum Completeness Criteria); the average students must take three remedial courses to complete (Putri 2019).

Remedial teaching conditions, especially for dealing with kinesthetic style students who are incomplete on the concept of projectile motion, must be immediately corrected. Putri (2019) states that if remedial teaching is not applied to an incomplete student, then the result will be: student scores remain low; students' understanding of concepts does not change or does not increase; students are not able to pursue others who are already completed in the learning (Jangid \& Inda 2016); there is no improvement if there is a misconception by the teacher that occur in students; students cannot answer UN (National Examination) questions related to the concept so as to reduce the passing grade in their physical subjects.

If in learning projectile motion concepts do not use props, then what will happen is: there is no media that can accommodate students with kinesthetic learning styles because there are no practical tools for projectile motion in schools, and the basic competencies that must be achieved in the concept of projectile motion are not optimally implemented, namely student's ability to present the results of projectile motion experiments (Kementrian Pendidikan dan Kebudayaan 2016). If learning media is not adapted to student learning styles such as kinesthetic style students (do not practice, simulate or demonstrate), then the result will be: not optimal in accepting learning, so that makes students difficult to understand the concepts (Zulfiani et al. 2018); quickly feels bored with the information obtained; start looking for attention with a variety of things that interfere; making noise while studying; annoying other friends; and indifferent when the teacher explains if students know their learning styles so they can formulate appropriate strategies to improve their ability in this way (Awang et al. 2017).

Kinesthetic style students who are incomplete in learning the concept of projectile motion can be overcome through remedial teaching using props. Remedial teaching can improve student weaknesses to improve student learning outcomes. Student learning outcomes can be improved by using props (Mishbahah 2017). The concept of physics is presented in multiple representations (Widianingtiyas et al. 2015) to accommodate student learning styles. The use of props in learning can make students actively involved, such as being able to observe, conduct experiments, and demonstrate (Anas 2014). These activities support the kinesthetic learning style. Media adapted to student learning styles will make it easier for students to understand the concepts. Hypermedia science-based learning style helps students who have different learning styles increase their understanding (Zulfiani et al. 2019). Projectile motion props can show the characteristics of projectile motion and the relationship between quantities in projectile motion. This media has added value compared to previous research: it does not require a long time in assembling tools; not muddy to avoid electrical short circuit; can draw a projectile track on the wall of the container so that the difference was seen in projectile motion when the angle and initial speed are changed; the diameter of the hose is made smaller so that it is more accurate in determining the initial angle (Putri 2019).

\section{METHODS}

The study was conducted in the odd semester of 2018/2019 at SMAN 4 South Tangerang City for three weeks from 13 to 27 November 2018, included the pretest to post-test activities. The research method used is the quasi-experiment method with a nonequivalent control group design. The design in this study was described (Silitonga 2018) as follows. 
TABLE 1. Research Design Nonequivalent Control Group Design

\begin{tabular}{|c|c|c|c|c|}
\hline & Group & Pretest & Treatment & Posttest \\
\hline & Experiment Group & $\mathrm{O}$ & $\mathrm{X}$ & $\mathrm{O}$ \\
\hline & Control Group & $\mathrm{O}$ & $X_{1}$ & $\mathrm{O}$ \\
\hline \multicolumn{5}{|c|}{ Information: } \\
\hline \multicolumn{5}{|c|}{$\begin{array}{l}\mathrm{O}=\text { pretest (initial test given before the treatment to both groups) and post-test (final test is given } \\
\text { after treatment to both groups) }\end{array}$} \\
\hline$X$ & \multicolumn{4}{|c|}{$=$ remedial teaching using a projectile motion props } \\
\hline & \multicolumn{4}{|c|}{$=$ remedial teaching by not using a projectile motion props } \\
\hline
\end{tabular}

Information:

Test instruments that are given to students have been validated by 16 experts, namely in physics, constructs, and language. The test results can be seen in TABLE 2 .

TABLE 2. Content Validity Test Results

\begin{tabular}{lcc}
\hline \multicolumn{1}{c}{ Rated Aspect } & CVI Score & Category \\
\hline Material content & 1.00 & Very suitable \\
Construction & 0.99 & Very suitable \\
Language & 0.97 & Very suitable \\
\hline
\end{tabular}

TABLE 2 shows that the test instruments used are appropriate in terms of the material, construct, and language. Thus, it can be concluded that the test instrument is valid and feasible to be implemented in research.

The test instrument was then applied to students. The test results were analyzed using Anates V4 software, which is presented in TABLE 3.

TABLE 3. Instrument Validity Test Results

\begin{tabular}{|c|c|c|}
\hline Test & The Results & Information \\
\hline Validity & $93.3 \%$ & $\begin{array}{l}\text { The number of questions used is } 14 \text { of } 15 \\
\text { questions }\end{array}$ \\
\hline Reliability & 0.82 (very high) & $\begin{array}{l}\text { The test instrument is reliable and is suitable } \\
\text { for use in research }\end{array}$ \\
\hline $\begin{array}{l}\text { Distinguishing } \\
\text { power }\end{array}$ & $\begin{array}{l}7.14 \% \text { (enough) } \\
71.43 \% \text { (good) } \\
21.43 \% \text { (very good) }\end{array}$ & $\begin{array}{l}\text { One question is categorized as "enough" } \\
\text { Ten questions are categorized as "good" } \\
\text { Three questions categorized as very "good" }\end{array}$ \\
\hline Difficulty level & $\begin{array}{l}21.4 \% \text { (easy) } \\
78.6 \% \text { (intermediate) }\end{array}$ & $\begin{array}{l}\text { Three easy questions } \\
\text { Eleven intermediate questions }\end{array}$ \\
\hline
\end{tabular}

The stage in this study began by giving a VARK learning style test to students of class X IPA in SMAN 4 South Tangerang City to find out students who have a kinesthetic learning style. The VARK learning style test instrument consists of four answer choices (Visual, Auditory, Read/Write, and Kinesthetic) with one score for each answer chosen. The determination of student learning styles (Fleming \& Mills 1992) determines based on the number of scores that dominates more than the four learning styles. For example, a student scoring two visual options (V), four auditory options (A), eight reads/write $(\mathrm{R})$ options, and two kinesthetic options $(\mathrm{K})$, then the student is considered to have a $\mathrm{read} / \mathrm{write}$ learning style. When there is an equal number of scores between two or more learning styles, the result is assumed that students have more than one learning style. The percentage calculation of student learning styles (Zulfiani et al. 2018) uses the formula:

$$
\%=\frac{\text { Type of learning style }}{\text { The number of students who havenot completed }} \times 100 \%
$$

Students who already know the learning style are given a pretest (projectile motion daily test) to find out the completeness of students on the concept. The incomplete kinesthetic style students are 
divided into two groups with the same number of students. Both groups were given treatment in the form of remedial teaching.

Remedial teaching in the experimental group used projectile motion props, while the control group did not use the props. Remedial teaching is carried out outside face-to-face hours (Direktorat Pembinaan SMA 2010). So, teaching and learning activities in class keep going well and do not interrupt finished students. Remedial teaching in both groups was conducted in two meetings. The first meeting is 90 minutes, and the second one is 45 minutes. Each meeting only re-teaches indicators that have not been achieved by students, including: (1) explaining the characteristics of projectile motion, (2) applying a projectile motion equation, and (3) finding a relationship between quantities in a projectile motion. After the treatment, the researcher gave a post-test to find out the student learning outcomes and gave a questionnaire to the experimental group to find out the students' responses to the projectile motion props that had been used. The research ended with analyzing the research data, testing the hypothesis, and drawing conclusions.

This study aims to determine: a) influence; b) improvement; c) effectiveness; and d) the response of students who use projectile motion props.

a. The next step is to analyze the research data in remedial teaching on kinesthetic style student learning outcomes. The influence of treatment come to light by testing the hypothesis through the T-test and U test using IBM SPSS 23 software.

b. The improvement in student learning outcomes uses the N-gain formula (Meltzer 2002).

$$
g=\frac{\text { posttest score }- \text { pretest score }}{\text { ideal score }- \text { pretest score }}
$$

The categories for N-gain values can be seen in TABLE 4.

TABLE 4. Classification of N-gain Values

\begin{tabular}{cc}
\hline Classification & Category \\
\hline $\mathrm{N}$-gain $>0.7$ & High \\
$0.3 \leq \mathrm{N}$-gain $\leq 0.7$ & Middle \\
$\mathrm{N}$-gain $<0.3$ & Low \\
\hline
\end{tabular}

c. The effectiveness of the treatment given to the two groups, it can be observed the number of students who get the post-test results above the MCC. The effectiveness criteria based on cognitive learning outcomes can be seen in the following TABLE 5 (Suwarna 2016).

TABLE 5. Effectiveness Criteria Based on Cognitive Learning Outcomes

\begin{tabular}{cc}
\hline Percentage & Criteria \\
\hline$\geq 80 \%$ & Very effective \\
$70 \%$ to $<80 \%$ & Effective \\
$60 \%$ to $<70 \%$ & Effective enough \\
$50 \%$ to $<60 \%$ & Less effective \\
$<50 \%$ & Ineffective \\
\hline
\end{tabular}

d. To find out students' responses to the use of projectile motion props can be known by using a Likert scale model with positive and negative statements. Likert scale conversion, according to Akdon (2010), can be seen in the following TABLE 6. 
TABLE 6. Conversion of Likert Scale

\begin{tabular}{lcc}
\hline \multirow{2}{*}{ Alternative Answers } & \multicolumn{2}{c}{ Score Rating Statement } \\
\cline { 2 - 3 } & Positive & Negative \\
\hline Strongly Disagree & 1 & 5 \\
Disagree & 2 & 4 \\
Enough & 3 & 3 \\
Agree & 4 & 2 \\
Strongly Agree & 5 & 1 \\
\hline
\end{tabular}

Then the data from the score acquisition is changed in the form of a percentage. Akdon (2010) use the formula:

$$
\text { Percentage }=\frac{\sum \text { score obtained }}{\sum \text { numberof responden } \$ \times 5} \times 100 \%
$$

Data in the form of percentages are interpreted using the score interpretation criteria in TABLE 7.

TABLE 7. Scoring Interpretation Criteria

\begin{tabular}{cc}
\hline Percentage & Criteria \\
\hline $0 \%$ to $<20 \%$ & Very bad \\
$20 \%$ to $<40 \%$ & Not good \\
$40 \%$ to $<60 \%$ & Enough \\
$60 \%$ to $<80 \%$ & Good \\
$80 \%$ to $<100 \%$ & Very good \\
\hline
\end{tabular}

\section{RESULTS AND DISCUSSION}

Remedial teaching is a treatment that can help students who are incomplete in obtaining learning goals that have not been achieved. Remedial teaching will be more optimal if it is adapted to student learning styles. The results of the analysis of student learning styles in SMAN 4 South Tangerang City are presented in FIGURE 1.

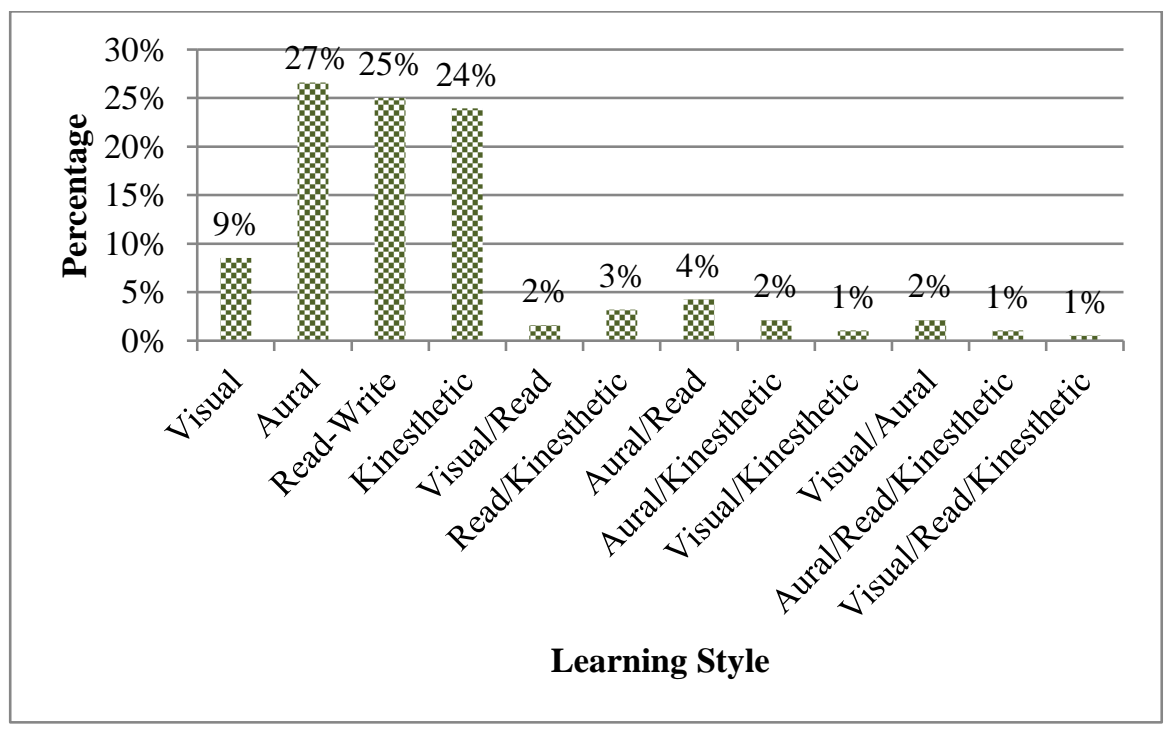

FIGURE 1. Learning Styles of 188 Students X IPA SMAN 4 South Tangerang City

FIGURE 1 shows student learning styles dominated by four VARK learning styles, Visual (9\%), Aural (27\%), Read-Write (25\%), and Kinesthetic (24\%) compared to mixed learning styles. Many 
students have a kinesthetic learning style so that it will significantly affect kinesthetic student learning outcomes if the learning process is not carried out by the learning style.

The results of the pretest (daily tests) showed that many students did not complete the concept of projectile motion (86\%). The 162 (out of 188) students get value below the minimum completeness $(\mathrm{MCC}=72)$. More than $50 \%$ of students do not complete the concept, so teachers must do remedial teaching. Of the $86 \%$ of students who did not complete, there were students with kinesthetic learning styles. The 50 (out of 56) kinesthetic style students did not complete the concept of projectile motion. Many kinesthetic style students are incomplete because the learning they do is not using media that is appropriate to their learning style. Kinesthetic style students obtain information by doing movements, touch, practice, or direct learning experience (Darmadi 2017).

The concentration and distribution of data values from the pretest-posttest based on statistical calculations are shown in the following TABLE 8.

TABLE 8. Measuring Centering and Disseminating Pretest Posttest Results of the Control Group and Experiment Group

\begin{tabular}{lllll}
\hline \multirow{2}{*}{$\begin{array}{l}\text { Centering and } \\
\text { Disseminating Data }\end{array}$} & \multicolumn{2}{c}{ Pretest } & \multicolumn{2}{c}{ Posttest } \\
\cline { 2 - 5 } & $\begin{array}{l}\text { Control } \\
\text { Group }\end{array}$ & $\begin{array}{l}\text { Experiment } \\
\text { Group }\end{array}$ & $\begin{array}{l}\text { Control } \\
\text { Group }\end{array}$ & $\begin{array}{l}\text { Experiment } \\
\text { Group }\end{array}$ \\
\hline Lowest Value & 7.14 & 14.29 & 35.71 & 50.00 \\
Highest Value & 71.43 & 71.43 & 92.86 & 92.86 \\
Mean & 43.14 & 42.57 & 62.86 & 81.14 \\
Median & 42.86 & 42.86 & 64.29 & 85.71 \\
Modus & 71.43 & 35.71 & 85.71 & 85.71 \\
Standard Deviation & 19.06 & 16.81 & 18.09 & 11.64 \\
\hline
\end{tabular}

TABLE 8 shows the pretest scores average of the two groups are still relatively low and not much different, namely 43.14 in the control group and 42.57 in the experimental group. So it can be said that both groups have the same ability before being given treatment. Based on the post-test results, the average value of the two groups increased, namely 62.86 in the control group and 81.14 in the experimental group. The improvement in both groups occurred after undergoing treatment in the form of remedial teaching. Through remedial teaching, the teacher can provide assistance to students who are slow learners, have difficulty, or fail to learn. Students can completely master the lessons given and can achieve the expected learning achievement through a process of remedial (Mukhtar 2007). The results of this study are relevant to previous studies that student learning outcomes improve after the application of remedial teaching (Bukhari 2017).

Student learning outcomes in both groups have increased. This can be seen from the average N-gain results presented in TABLE 9.

TABLE 9. Average N-gain Results of the Control Group and Experiment Group

\begin{tabular}{lcc}
\hline \multicolumn{1}{c}{ Group } & $\boldsymbol{N}$-gain & Category \\
\hline Control & 0.31 & Middle \\
Experiment & 0.64 & Middle \\
\hline
\end{tabular}

TABLE 9 shows the $\mathrm{N}$-gain score for the control group was 0.31 , and the $\mathrm{N}$-gain score for the experimental group was 0.64 . Improved student learning outcomes kinesthetic style in both groups is in the middle category. Even though the two groups were in the moderate category, it was seen that the increase in learning outcomes of the experimental group was higher than the control group. That is because, during the remedial teaching, the experimental group used projectile motion props. Remedial teaching using these props is very effective in applying kinesthetic style students. The results of the effectiveness test are presented in TABLE 10. 
TABLE 10. Effectiveness Test Results

\begin{tabular}{lcc}
\hline Group & $\begin{array}{c}\text { Percentage of } \\
\text { Students who } \\
\text { Achieve MCC }\end{array}$ & Criteria \\
\hline Experiment & $80 \%$ & Very effective \\
Control & $28 \%$ & Ineffective \\
\hline
\end{tabular}

TABLE 10 shows that $80 \%$ of the experimental group students scored above the KKM $(\mathrm{KKM}=$ 72). This shows that remedial teaching using projectile motion media is very effective in kinesthetic style students. The use of a projectile motion props in remedial teaching has a positive impact on kinesthetic style student learning outcomes that is not complete on the concept of projectile motion. Students learn in different ways; the use of props is a way to accommodate various types of learning styles (Yaumi 2018). Previous research (Nafisah et al. 2018) states that the use of props can improve student cognitive learning outcomes so that student learning outcomes are complete. While the control group students who reached the MCC only $28 \%$. That is because the control group students did not use the projectile motion props so that they did not get treatment according to their learning style, namely the kinesthetic learning style. It is necessary for teachers or instructors to accommodate student learning styles in designing and implementing learning programs (Pribadi 2011). Previous research (Nurlia et al. 2017) stated that learning styles have a powerful relationship with student learning outcomes. It will be easier for the student to understand or accept the information obtained if the information is conveyed according to their learning style. Othman and Amiruddin (2010) stated that appropriate and effective learning styles could help students to achieve achievement in their learning.

Student learning outcomes based on post-test results in the cognitive domain also increased. The increase based on the results of the N-gain presented in TABLE 11 and FIGURE 2.

TABLE 11. Average Results of N-gain Levels of Cognitive Domains C2, C3, C4 Control Group, and Experiment Group

\begin{tabular}{ccccc}
\hline Cognitive & \multicolumn{4}{c}{$\boldsymbol{N}$-gain } \\
\cline { 2 - 5 } Domains & Control & Information & Experiment & Information \\
\hline C2 & 0.50 & Middle & 0.72 & High \\
C 3 & 0.38 & Middle & 0.41 & Middle \\
C4 & 0.02 & Low & 0.62 & Middle \\
\hline
\end{tabular}

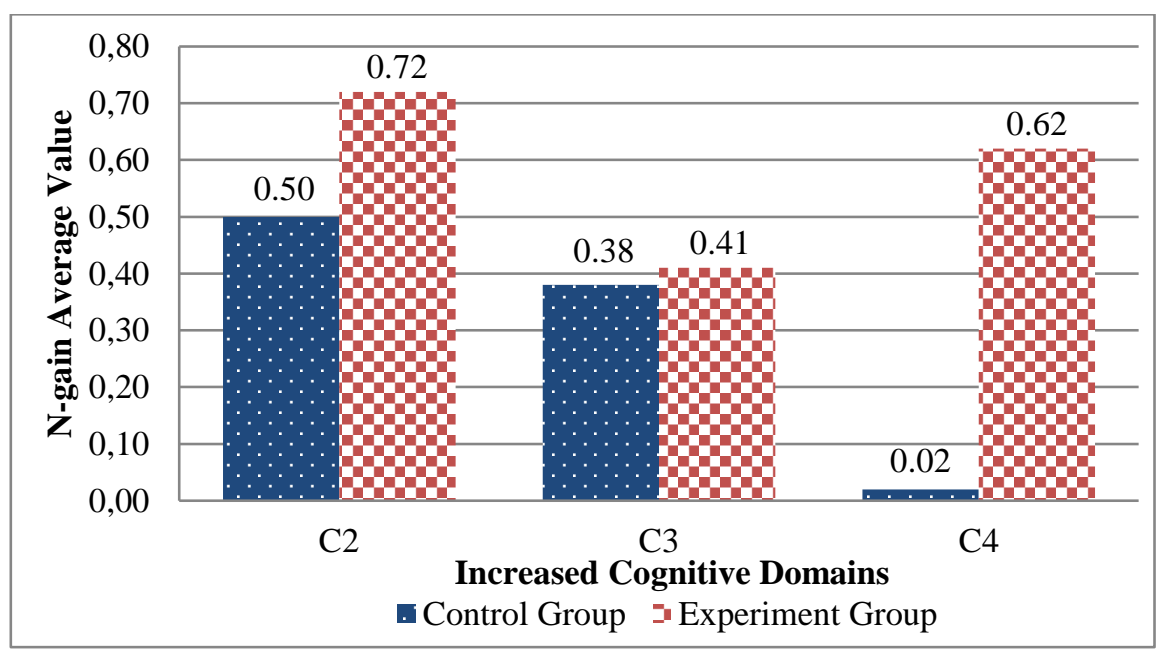

FIGURE 2. Bar chart of C2, C3, C4 N-gain Cognitive Domains Control, and Experiment Groups

TABLE 11 and FIGURE 2 shows the differences in the average N-gain cognitive domains C2, C3, and $\mathrm{C} 4$ in the control and experimental groups. The average $\mathrm{N}$-gain score of the control group in the $\mathrm{C} 2$ cognitive domain is 0.50 (moderate); the $\mathrm{C} 3$ cognitive domain is 0.38 (moderate), and the cognitive domain $\mathrm{C} 4$ is 0.02 (low). While the average $\mathrm{N}$-gain score of the experimental group in the $\mathrm{C} 2$ cognitive 
domain is 0.72 (high), the $\mathrm{C} 3$ cognitive domain is 0.41 (moderate), and the cognitive domain $\mathrm{C} 4$ is 0.62 (moderate).

The increase in cognitive domain $\mathrm{C} 2$ (understanding) in the experimental group was superior to the control group with a difference of 0.20 . The difference is far between the two groups because, in remedial teaching, the experimental group uses projectile motion props. These props can show the characteristics of the projectile motion. Besides, the props can present the phenomenon of projectile motion in more real terms students can understand the concept better, such as it is easier to visualize the trajectory of the movement of objects after being given the initial angle while students in the controlled group understood the concept of projectile motion verbally. Students are not presented with a phenomenon that can visualize projectile motion in real terms, so it is less effective in understanding the concept.

In the cognitive domain C3 (applying), the two groups also experienced an increase. Both groups experienced an increase in the middle category with different treatments. Remedial teaching in control group students is given examples of problems related to the concept of projectile motion so that students can apply projectile equations in solving problems. In contrast, the experimental group students can apply the equations to the concept of projectile motion after discovering the relationship between the quantities in the concept through projectile motion props.

In addition to an increase in learning outcomes in the cognitive domains $\mathrm{C} 2$ and $\mathrm{C} 3$, both groups also experienced an increase in learning outcomes in the cognitive domain $\mathrm{C} 4$ (analyzing). The increase between the two groups had a huge difference of 0.60 . The difference in improvement between the two groups is due to the students in the experimental group using projectile motion props. These props can find the relationship between quantities in projectile motion. Students of the experimental group will more easily analyze problems related to the concept and can predict the farthest distance of objects after being given different angles. While the control group students had difficulty because they were not given the opportunity to construct their knowledge and were not involved in the overall learning.

Students of the experimental group were more enthusiastic about learning the projectile motion again by using props. This is evident from the results of the student response questionnaire presented in TABLE 12.

TABLE 12. Kinesthetic Style Student Responses to the Use of Projectile Motion Props

\begin{tabular}{lcc}
\hline \multicolumn{1}{c}{ Questionnaire Indicator } & $\begin{array}{c}\text { Percentage } \\
\text { of Student Responses }\end{array}$ & Interpretation \\
\hline The use of projectile motion props & $79 \%$ & Good \\
$\begin{array}{l}\text { Submission of material concepts } \\
\text { The advantages of projectile motion }\end{array}$ & $81 \%$ & Very good \\
props & $82 \%$ & Very good \\
\hline Average & $81 \%$ & Very good \\
\hline
\end{tabular}

TABLE 12 shows the average percentage of kinesthetic style students' responses to the use of projectile motion props in remedial teaching on the concept of projectile motion is in a "very good category" that is $81 \%$. This shows the use of projectile motion props can make students more motivated and better understand the concept of projectile motion. This shows that if the media used in learning is adapted to student learning styles, it will increase motivation and understanding of concepts in students. The statement is relevant to previous research (Khongpit et al. 2018) that the teaching material design should be done by creating creative activities and environments that environment that suits the learning style to increase student motivation and understanding to improve student achievement.

The T-test results for pretest data and $\mathrm{U}$ test for post-test data produce different decisions, which can be seen in TABLE 13. 
TABLE 13. Hypothesis Test Results

\begin{tabular}{ccc}
\hline & $\begin{array}{c}\text { Pretest } \\
(\boldsymbol{T} \text {-Test) }\end{array}$ & $\begin{array}{c}\text { Posttest } \\
\text { (Mann-Whitney U Test) }\end{array}$ \\
\hline Sig. (2-tailed) & 0.911 & 0.000 \\
$\alpha$ & & 0.05 \\
Decision & $H_{l}$ Rejected & $H_{1}$ Accepted \\
\hline
\end{tabular}

TABLE 13 shows that there is a significant influence on the use of projectile motion props on kinesthetic style student learning outcomes. It can be seen from the significance value $>0.05$, then $\mathrm{H}_{0}$ is accepted, and $\mathrm{H}_{1}$ is rejected. The significance value of the pretest data $(0.911>0.05)$, so it can be concluded that there is no difference in the average pretest learning outcomes of the control and experimental students. While the significance value of the post-test data $(0.000<0.05)$, there are differences in the average post-test learning outcomes of the control group and experimental students.

The props used were validated. The validation of media and material experts provided valid responses (Putri 2019). There are eight aspects of media assessment, namely: (1) criteria for conformance with teaching materials, (2) tool durability, (3) accuracy, (4) tool efficiency, (5) tool safety, (6) aesthetics, (7) tool completeness, and (8) tool storage whereas material expert judgment covers two aspects, namely, the suitability of the content and concept.

The projectile motion props used in this study has several advantages in improving student learning outcomes (Putri 2019) including 1) can present information following student learning styles namely kinesthetic learning styles so that kinesthetic style students will more easily accept information submitted; 2) can present the phenomenon of projectile motion continuously so students can visualize the movement of objects that form the path of a projectile and know the characteristics of projectile motion; 3) can apply projectile equations related to data obtained from the results of experiments so that students not only memorize formulas but can find out the phenomena associated with these formulas, and 4) can find the relationship between quantities in projectile motion so that students will more easily analyze problems related to the concept of projectile motion.

The arrangement of a series of projectile motion props can be seen in FIGURE 3.

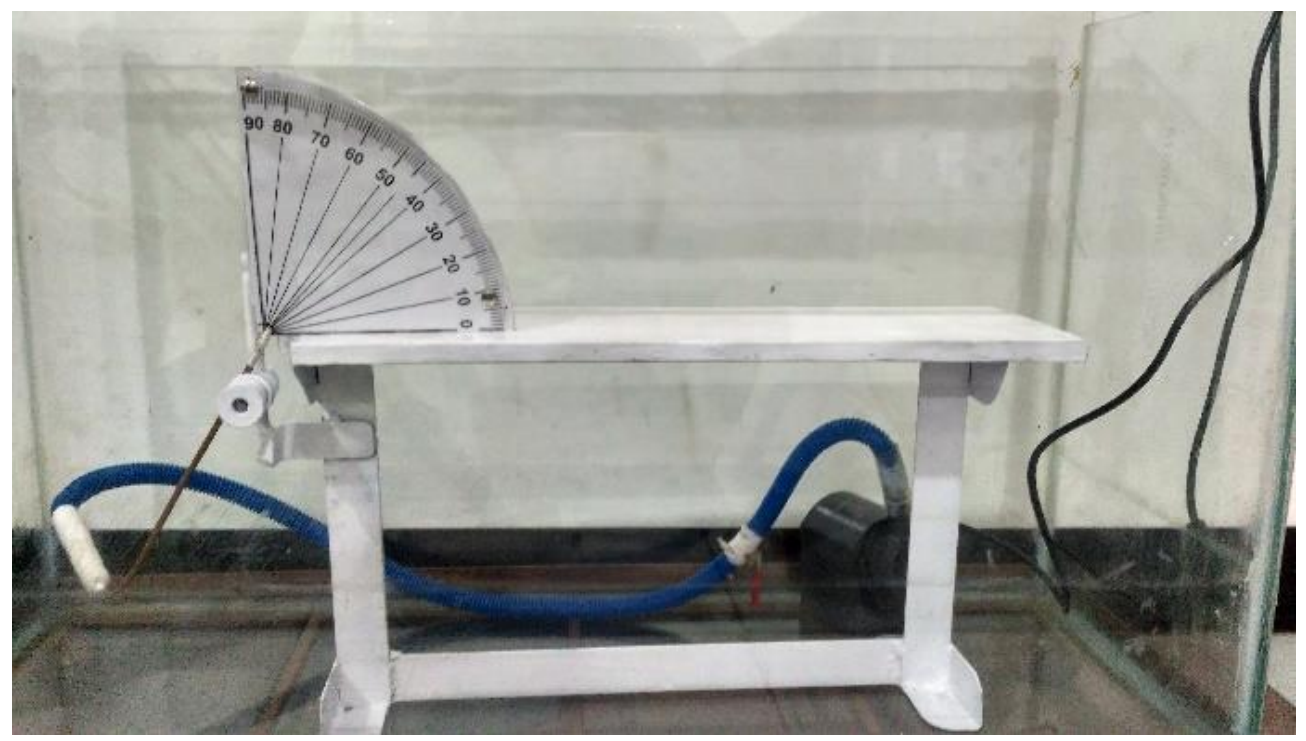

FIGURE 3. Arrangement of Projectile Motion Props Series 
The components of a projectile motion props can be seen in FIGURE 4.

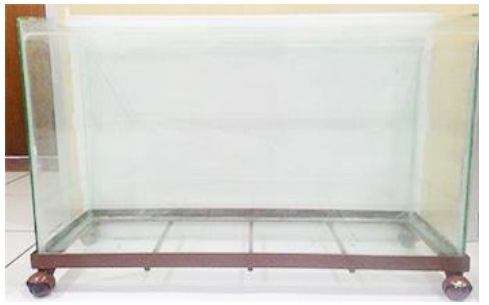

(a)

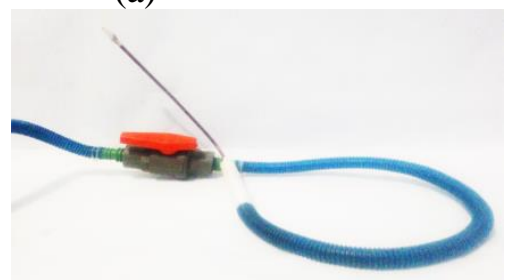

(d)

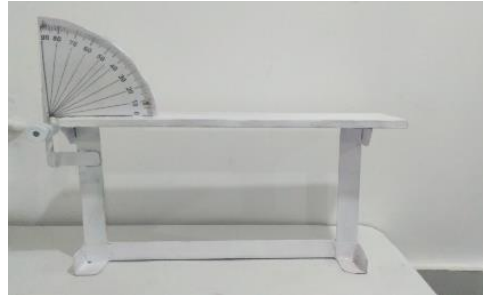

(b)

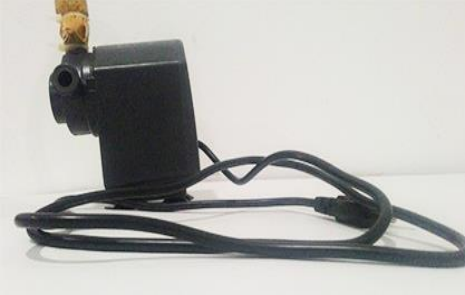

(c)

FIGURE 4. (a) Glass container to hold water and store props, (b) Protractor to measure angles on hoses and track tables to support water that falls when water is emitted, (c) Circulator pump to push water from a shelter to the hose, (d) Tap to regulate the velocity of water coming out of the end of the hose and the hose functions to channel water and emit water from the reservoir, (e) Ruler to measure distance and height of the water.

\section{SUMMARY}

There is an influence of the use of projectile motion props on kinesthetic style student learning outcomes in remedial teaching. Student learning outcomes in the experimental group increased higher than in the control group. Improved learning outcomes of the experimental group experienced the highest increase in cognitive domain $\mathrm{C} 2$ with an $\mathrm{N}$-gain of 0.72 . Remedial teaching using projectile motion props is very effective in which 20 students $(80 \%)$ of the experimental group can achieve MCC, while in the control group, only seven students $(28 \%)$ reach MCC. The use of projectile motion props helps kinesthetic style students understand the concept of projectile motion. The student response was very good $(81 \%)$ on the use of the props. Therefore, teachers who want to do remedial teaching on the concept of projectile motion are highly recommended to use a projectile motion props because it is very effective in overcoming students' kinesthetic style that is incomplete on the concept. This prop is expected to be developed by adding sensors to produce accurate time to show the relationship between elevation angle and initial velocity with travel time.

\section{REFERENCES}

Akdon, R 2010, Rumus dan data dalam aplikasi statistika, Alfabeta, Bandung.

Anas, M 2014, Alat peraga dan media pembelajaran, Muhammad Anas.

Awang, H, Samad, NA, Faiz, NM, Roddin, R \& Kankia, JD 2017, 'Relationship between the learning styles preferences and academic achievement', IOP Conference Series: Materials Science and Engineering, vol. 226, no. 1, p. 012193.

Bukhari, B 2017, 'Penerapan pengajaran remedial terhadap peningkatan hasil belajar siswa pada pokok bahasan ikatan ion dan ikatan kovalen', Jurnal Dedikasi Pendidikan, vol. 1, no. 1, pp.11-20.

Darmadi, H 2017, Pengembangan model dan metode pembelajaran dalam dinamika belajar siswa, Deepublish, Yogyakarta

Direktorat Pembinaan SMA 2010, Juknis Pembelajaran Tuntas, Remedial, dan Pengayaan di SMA, Depdikbud. 
Fleming, ND \& Mills, C 1992, 'Not another inventory, rather a catalyst for reflection', To improve the academy, vol. 11, no. 1, pp.137-155.

Jangid, N \& Inda, US 2016, 'Effectiveness of remedial teaching on thinking strategies of slow learners', The International Journal of Indian Psychology, vol. 4, no.1, p. 84.

Kementrian Pendidikan dan Kebudayaan 2016, Silabus mata pelajaran sekolah menengah atas/madrasah aliyah (SMA/MA) mata pelajaran fisika, Kemdikbud, Jakarta.

Khongpit, V, Sintanakul, K \& Nomphonkrang, T 2018, 'The VARK learning style of the university student in computer course', International Journal of Learning and Teaching, vol. 4, no. 2.

Meltzer, DE 2002, 'The relationship between mathematics preparation and conceptual learning gains in physics: A possible "hidden variable" in diagnostic pretest scores', American journal of physics, vol. 70, no. 12, pp. 1259-1268.

Mishbahah, P 2017, 'Pengembangan alat peraga percobaan melde sebagai media pembelajaran fisika pada materi gelombang stasioner', Jurnal Inovasi Pendidikan Fisika (JIPF), vol. 6, no 3, pp. 275279.

Mukhtar, R 2007, Pengajaran remedial: Teori dan penerapannya dalam pembelajaran, Nimas Multima, Jakarta.

Nafisah, D, Sulhadi, S \& Yulianti, D 2018, 'Pembelajaran fisika berbantuan alat peraga proyektor smartphone untuk meningkatkan pemahaman konsep optik pada siswa SMP', UPEJ Unnes Physics Education Journal, vol. 7, no. 1, pp. 74-80.

Nurlia, N, Hala, Y, Muchtar, R, Jumadi, O \& Taiyeb, M 2017, 'Hubungan antara gaya belajar, kemandirian belajar, dan minat belajar dengan hasil belajar biologi siswa', Jurnal Pendidikan Biologi, vol. 6, no. 2, pp. 321-328.

Othman, N \& Amiruddin, MH 2010, 'Different perspectives of learning styles from VARK model', Procedia-Social and Behavioral Sciences, vol. 7, pp. 652-660.

Pribadi, BA 2011, Model assure untuk mendesain pembelajaran sukses, Dian Rakyat, Jakarta.

Putri, SE 2019, 'Pengaruh alat peraga gerak parabola pada remedial teaching terhadap hasil belajar siswa kinesthetic style', Bachelor's thesis, Repisitori UIN Syarih Hidayatullah Jakarta.

Saepuzaman, D, \& Karim, S 2016, 'Desain pembelajaran student's conceptual construction guider berdasarkan kesulitan mahasiswa calon guru fisika pada konsep gerak parabola', Jurnal Penelitian \& Pengembangan Pendidikan Fisika, vol. 2, no. 2, pp. 79-86.

Silitonga, FS 2018, 'The using of peer tutoring learning method in improving student's understanding', First Indonesian Communication Forum of Teacher Training and Education Faculty Leaders International Conference on Education 2017, pp. 183-186.

Suwarna, IP 2016, 'Pengembangan instrumen ujian komprehensif mahasiswa melalui computer based test pada program studi pendidikan fisika', Bachelor's thesis, Repisitori UIN Syarih Hidayatullah Jakarta.

Wicaksana, A 2017, 'Pengembangan Alat Peraga Pada Materi Gerak Parabola Untuk Melatih Keterampilan Proses Sains Siswa (Bachelor's thesis)', Bachelor's thesis, Repisitori UIN Syarih Hidayatullah Jakarta.

Widianingtiyas, L, Siswoyo, \& Bakri, F 2015, 'Pengaruh pendekatan multi representasi dalam pembelajaran fisika terhadap kemampuan kognitif siswa SMA', Jurnal Penelitian \&Pengembangan Pendidikan Fisika, vol. 1, no. 1, pp. 31-38.

Yaumi, M 2018, Media dan Teknologi Pembelajaran, Prenada Media, Jakarta.

Zulfiani, Z, Suwarna, IP \& Miranto, S 2018, 'Science education adaptive learning system as a computer-based science learning with learning style variations', Journal of Baltic Science Education, vol. 17, no. 4, pp. 711-727. 
Zulfiani, Z, Suwarna, IP \& Miranto, S 2019, 'ScEd-ALS Project: The use of pedagogical intervention in developing hypermedia science based on learning style', Empowering Science and Mathematics for Global Competitiveness: Proceedings of the Science and Mathematics International Conference (SMIC 2018), November 2-4, 2018, Jakarta, Indonesia, pp. 223-232. 